
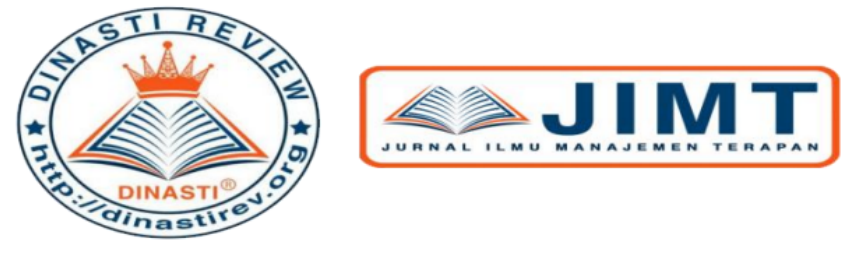

+62 878-9658-6407

087896586407

https://dinastirev.org/JIMT

editor@dinastirev.org

\title{
PENGEMBANGAN PENDIDIKAN TINGGI BERORIENTASI KEWIRAUSAHAAN DALAM PERSPEKTIF GLOBAL
}

\author{
Maisah $^{1)}$, Sohiron ${ }^{2)}$, Ahmad Hariandi ${ }^{3)}$, Ahmad Sopian'), Qalka Sandi' ${ }^{5}$ \\ 1) Universitas Islam Negeri Sultan Thaha Saifuddin Jambi, Jambi, Indonesia \\ 2 )Universitas Islam Negeri Sultan Syarif Kasim Riau, Riau, Indonesia \\ 3 )Universitas Jambi, Jambi, Indonesia \\ ${ }^{4}$ )Sekolah Tinggi Ilmu Tarbiyah Raudhatul Ulum Sakatiga, Palembang, Indonesia \\ 5 )Sekolah Tinggi Ilmu Tarbiyah YPI Lahat, Palembang, Indonesia
}

\begin{tabular}{|c|c|}
\hline $\begin{array}{l}\text { ARTICLE INFORMATION } \\
\text { Received: } 12 \text { Maret } 2020 \\
\text { Revised: } 17 \text { Maret } 2020 \\
\text { Issued: } 23 \text { Maret } 2020\end{array}$ & $\begin{array}{l}\text { Abstrak: Kajian ini bertujuan mendeskripsikan } \\
\text { pengembangan pendidikan tinggi yang berorientasi } \\
\text { kewirausahaan dalam perspektif global. Penelitian ini } \\
\text { menggunakan metode deskriptif-kualitatif. Hasil dari } \\
\text { penelitian ini menunjukan bahwa pendidikan tinggi di } \\
\text { era globalisasi mengharuskan mampu melahirkan } \\
\text { alumni yang memiliki daya saing, salah satu } \\
\text { indikatornya adalah memiliki jiwa kewirausahaan. } \\
\text { Untuk itu perguruan tinggi kurikulum pendidikan } \\
\text { berbasis kewirausahaan (Curriculum-Based } \\
\text { Entrepreneurship) hal ini akan menjadi media } \\
\text { menyiapkan lulusan yang memiliki jiwa wirausaha dan } \\
\text { siap bersaing di masyarakat dengan berbagai } \\
\text { keterampilan. Adapun strategi pendidikan } \\
\text { kewirausahaan sebaga berikut: 1). menyusun } \\
\text { kurikulum; 2). peningkatan sdm dosen; } 3 \text { ). membentuk } \\
\text { entrepreneurship centre; 4). membentuk unit usaha; 5). } \\
\text { kerjasama dengan institusi keuangan (perbankan/non } \\
\text { perbankan); dan 6). entrepreneurship award. Salain } \\
\text { strategi pengembangan kurikulum pendidikan } \\
\text { kewirausahaan, perguruan tinggi juga dapat } \\
\text { menerapkan tata kelola pendidikan tingg dengan sistem } \\
\text { ala bisnis (business like) sehingga pemberian layanan } \\
\text { publik menjadi lebih efisien dan efektif. } \\
\text { Kata Kunci: Pendidikan Tinggi, kewirausahaan, } \\
\text { globalisasi. }\end{array}$ \\
\hline
\end{tabular}

\section{PENDAHULUAN}

Globalisasi sering digambarkan sebagai sebuah babak sejarah dimana setiap negara beserta individunya harus mampu bersaing satu sama lain baik antar negara maupun antar individu. Globalisasi dapat diartikan sebagai internasionalisasi. Di sini, globalisasi dipandang sebagai hubungan lintas-perbatasan antara negara-negara. Menurut (Hirst \& Thompson: 2000) 
globalisasi menggambarkan pertumbuhan dalam pertukaran internasional dan saling ketergantungan. Dengan arus pertumbuhan perdagangan dan investasi modal memungkinkan ekonomi nasional bergerak melampaui ekonomi internasional (dengan entitas prinsip adalah ekonomi nasional) untuk menjadi lebih kuat - ekonomi global adalah sebuah proses di mana ekonomi nasional yang berbeda-beda diintegrasikan ke dalam sistem oleh proses dan transaksi internasional.

Globalisasi dalam bidang ekonomi menurut Jamaluddin 'Atiyah dalam (Hamzah: 2014) menyatakan globalisasi ekonomi menyatukan seluruh dunia kepada satu pasar bebas (free market) atau pemindahan kepemilikan umum dan perseroan-perseroan kepemilikan khusus untuk mengurangi pengawasan dan campur tangan pemerintah dalam negeri.

Abad 21 Indonesia dihadapkan pada era MEA (Masyarakat Ekonomi Asian) sebagai bentuk konsekuensi globlalisasi dimana pada masa ini seluruah bangsa di ASIAN berbenah dalam menyiapkan produk sumber daya manusia (Human Resource) yang mampu untuk bardaya saing dibidang ekonomi. Dalam konteks ini sumberdaya manusia sangatlah utama untuk menyambut masyarakat ekonomi Asia tersebut. Bila tidak siap bersaing, maka negara Indonesia akan dijajah secara ekonomi oleh negara-negara di Asia. Era globlalisasi, bila suatu negara tidak berbenah untuk meningkatkan kompetesi sumber daya manusia maka kita akan menjadi konsumen di negeri sendiri.

Undang-Undang 12 tahun 2012 tentang perguruan tinggi untuk mennciptakan lulusan yang memiliki kompetensi yang siap pakai sesuai dengan bidang keilmuan baik secara vokasi maupun secara profesi. Oleh karena itu, perguruan tinggi wajib merencanakan kurikulum yang mampu menyiapkan lulusan yang memiliki kompetansi. Mencermati dampak lulusan perguruan tinggi sesuai dengan Peraturan Pemerintah nomor 8 tahun 2012 bahwa dalam pengelolaan perguruan tinggi untuk mampu berpedoman pada Standar Nasional Perguruan Tinggi Indonesia (SNPT) dan Peraturan Menteri Riset, Teknologi dan Pendidikan Tinggi (Permenristekdikti) nomor 44 tahun 2015, perguruan tinggi didorong untuk menciptakan lulusan yang memiliki Kwalifikasi Kompetensi Nasional Indonesia (KKNI).

Dengan demikian, dipandang perlu untuk mengembangkan struktur kurikulum yang disesuaikan dengan perkembangan teknologi dan pengembangan lingkungan, sehingga lulusan memiliki daya saing di era globalisasi. Untuk itu, perguruan tinggi perlu mengemas kurikulum berbasis kewirausahaan (Curriculum - Based Entrepreneurship) hal ini akan menjadi media menyiapkan lulusan yang memiliki jiwa wirausaha dan siap bersaing di masyarakat dengan berbagai keterampilan. Sehingga lulusan perguruan tinggi siap untuk menciptakan pekerjaan (ready for use) dan menjadi SDM yang bukan mencari pekerjaan tetapi menciptakan pekerjaan. Suatu negara akan mencapai kemakmuran jika $2 \%$ dari jumlah penduduk menjadi pengusaha. Kewirausahaan suatu bangsa dapat menjaga pertumbuhan dalam jangka panjang, maka dibutuhkan wirausaha minimal $2 \%$ dari jumlah penduduk. Namun, Indonesia hanya memiliki 0,24\% dari jumlah penduduk Indonesia sekitar 248 juta jiwa pada tahun 2014. Sehubungan dengan pentingnya kewirausahaan untuk pertumbuhan kesejahteraan, kemajuan, dan kenyamanan masyarakat, maka lembaga pendidikan tinggi swasta perlu membekali calon lulusan/ mahasiswa baik diploma maupun strata 1 agar dapat melakukan kemandirian dalam kehidupannya. Untuk itu, perlunya kurikulum berbasis kewirausahaan di selenggarakan di perguruan tinggi.

Era reformasi dan globalisasi perguruan tinggi di Indonesia bercorak desentralisasi dengan penekanan pada sumberdaya manusia sebagai unsur utama dalam pengembangan dinamika pengelolaan pelayanan publik sudah sesuai dengan semangat proses reformasi birokrasi di lingkungan instansi pelayanan publik.

Diberlakukannya Undang-undang Nomor 17 Tahun 2003 tentang Keuangan Negara dan Undang-undang Nomor 1 Tahun 2004 tentang Perbendaharaan Negara mencerminkan adanya perubahan sistem penganggaran tradisional menjadi penganggaran berbasis kinerja. 
Dengan system penganggaran berbasis kinerja (performance based budgeting), penyusunan dan pelaksanaan anggaran tidak hanya berdasarkan input dan proses saja, tetapi berorientasi pada output (hasil kinerja). Adapun sistem untuk meningkatkan pelayanan kepada masyarakat dalam rangka memajukan kesejahteraan umum dan mencerdaskan kehidupan bangsa dibentuk Badan Layanan Umum (BLU) (Pasal 68 UU Nomor 1 tahun 2004).

BLU diimplementasikan pada satuan-satuan kerja pemerintah yang secara fungsional melaksanakan tugas operasional pelayanan publik, seperti layanan kesehatan, pendidikan, pengelolaan kawasan, dan lisensi, untuk membedakannya dari fungsi pemerintah sebagai regulator dan penentu kebijakan. Praktik ini telah berkembang luas di manca negara berupa upaya pengagenan (agencification) aktifitas yang tidak harus dilakukan oleh lembaga birokrasi murni, tetapi diselenggarakan oleh instansi yang dikelola ala bisnis (business like) sehingga pemberian layanan kepada masyarakat menjadi lebih efisien dan efektif (Sulasi Rongiati: 2011). Perguruan Tinggi Negeri salah satu instansi yang dijinkan secara penuh untuk menerapkan Pengelolaan Keuangan Badan Layanan Umum (PK-BLU), maka pengelolaan keuangan dapat dilakukan lebih fleksibel, dengan mengutamakan produktivifitas, efisiensi dan efektivitas. Pola pengelolaan keuangan BLU dimaksudkan agar Perguruan Tinggi Negeri sebagai instansi pemerintah dapat meningkatkan pelayananannya kepada pelanggan, dalam hal ini mahasiswa, masyarakat, dan para stakeholder. Perguruan tinggi negeri sebagai satuan pemerintah yang menerapkan BLU dapat mengelola unit-unit usaha sebagai sumber pendapatan BLU perguruan tinggi (Pasal 14 dan 27 PP 23 tahun 2005 tentang PK-BLU).

Dengan demikian, perguruan tinggi negeri yang telah ditetapkan PTN-BLU harus mengembangkan unit-unit usaha perguruan tinggi dengan semangat enterpreneurship (kewirausahaan) sehingga akan memberi nilai tambah bagi perguruan tinggi negeri serta meningkatkan pelayanan prima dan kesejahteraan stakeholder kampus.

\section{KAJIAN PUSTAKA}

\section{Teori Kewirausahaan}

Kewirausahaan (entrepreneurship) adalah suatu proses membelai bisnis baru, mengorganisasikan sumberdaya-sumberdaya seperti; sumberdaya manusia (tenga kerja), sumberdaya alam (bahan baku) yang diperlukan untuk kegiatan pemberian nilai tambah ekonomis (economic value addded) yang akan menghasilkan produk, baik barang maupun jasa dengan mempertimbangkan risiko yang terkait dan balas jasa yang akan diterima dari aktivitas penjualan produk barang maupun jasa (Dedy Takdir S, dkk: 2015). Menurut Stepen P. Robbins dan Merry Coulter kewirausahaan adalah proses dimana seorang individu atau kelompok individu menggunakan upaya terorganisir dan sarana untuk mengejar peluang untuk menciptakan nilai dan tumbuh dengan memenuhi keinginan dan kebutuhan melalui inovasi dan keunikan, tentang masalah sumber daya apa yang saat ini dikendalikan (Dedy Takdir S, dkk: 2015). Menurut Norman M. Scarborough dan Thomas W. Zimmerer Kewirausahaan adalah tindakan manusia, kreatif yang membangun sesuatu yang bernilai, mengejar peluang terlepas dari kelebihan atau kekurangan sumber daya. Untuk itu diperlukan visi, gairah dan komitmen untuk memimpin orang lain dalam mengejar visi. Hal ini juga diperlukan kemauan untuk mengambil risiko yang telah diperhitungkan (Dedy Takdir S, dkk: 2015). Menurut PierreAndre Julien Kewirausahaan didefinisikan sebagai cara memandang berbagai hal dan proses menciptakan dan mengembangkan kegiatan ekonomi yang didasarkan pada risiko, kreativitas dan inovasi, dan selanjutnya dikelola dalam organisasi baru atau yang sudah ada (Pierre-Andre Julien: 2007).

Dengan demiakian, kewirausahaan adalah suatu kemampuan, kreatifitas dan inovasi yang terus menerus dalam membangun sesuatu yang memberi nilai atau bisnis dengan mempertimbang resiko yang ada dan dengan memanfaatkan sumber daya organisasi, baik organisasi baru atau yang sudah ada. 
Kegiatan wirausaha dapat dijalankan seseorang atau sekelompok orang (Kasmir: 2011). Dengan demikian, kegiatan kewirausahaan dapat dijalankan secara pribadi maupun secara kelompok orang atau organisasi dalam membuka dan menjalankan usaha dalam rangka memberi dan meningkatkan nilai lebih bagi pribadi mapun organisasi pelaku usaha serta masyarakat luas.

Teori model kewirausahaan mengacu pada teori Resource-Based View (RBV) dari perusahaan, modal manusia, modal sosial, pembelajaran organisasi, dan kognisi kreatif terintegrasi dalam pekerjaan perusahaan. Integrasi ini penting karena membahas bagaimana menggabungkan dan mensintesis pencarian peluang perilaku dan perilaku mencari keuntungan mengarah pada penciptaan kekayaan (Ireland, at all: 2003). Dimensi Entreprenurial Mindset, Entreprenurial Culture, dan Entreprenurial Leadership merupakan komponen pada sesi utama integrasi tersebut, yang dapat dilihat pada gambar berikut:

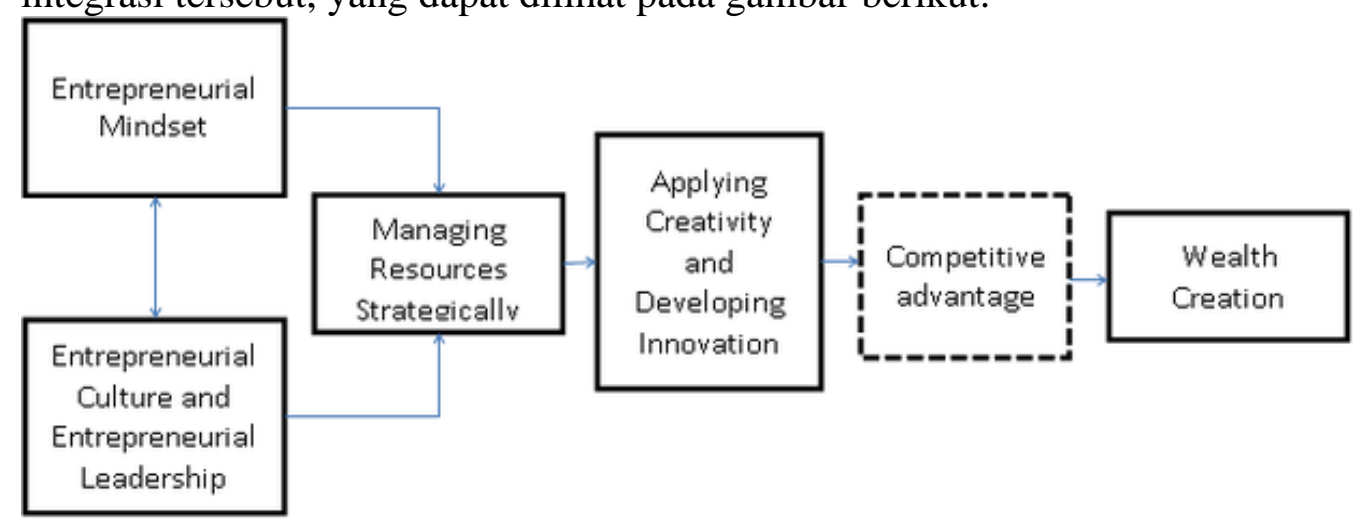

\section{Gambar 1: Model Kewirausahaan}

Berdasarkan gambar 1 di atas, Ada 3 komponen dari entrepreneurial mindset, diantaranya adalah sebagai berikut:

a. Mengenali peluang entrepreneurial

Peluang entrepreneurial muncul ketika barang baru, jasa, bahan baku, dan metode pengaturan diperkenalkan dan dijual dengan harga melebihi biaya produksi. Peluang ini muncul karena adanya informasi asimetris antar individu dalam mengembangkan keyakinan tentang nilai saat ini suatu sumber daya serta nilai masa depan ketika sumber daya akan ber transformasi dari input menjadi output. Perubahan-perubahan yang menyebabkan munculnya segmen pasar baru dapat menciptakan peluang entrepreneurial.

\section{b. Entrepreneurial alertness}

Sering disebut sebagaiflashes of superior insight. Hal ini berarti mampu dalam mengidentifikasi barang atau jasa menjadi layak. Selain itu, barang atau jasa yang ada menjadi berharga bagi konsumen. Wawasan entrepreneur mempengaruhi pencarian pasar yang diterapkan pada barang atau jasa baru. Entrepreneur yang siap siaga menunjukkan bahwa mereka memiliki entrepreneurial mindset. Hal ini akan terlihat seperti suatu kebiasaan dengan beberapa karakteristik, termasuk memiliki semangat dalam mengejar peluang, disiplin dalam mengejar peluang yang menjanjikan, konsisten dan fokus pada eksekusi, serta berkomitmen untuk melibatkan semua orang dalam mengidentifikasi dan mengejar peluang.

\section{c. Entrepreneurial framework}

Termasuk di dalamnya tindakan-tindakan seperti menetapkan tujuan-tujuan, menciptakan daftar peluang-peluang, dan menentukan waktu yang tepat sehubungan dengan peluncuran strategi yang dibutuhkan untuk mengeksploitasi peluang entrepreneurial. Selain itu, framework ini harus digunakan secara berkesinambungan sepanjang pelaksanaan dan waktu pengerjaan proyek untuk memastikan adanya perlakuan yang sama sebagaimana perusahaan mengevaluasi alternatif-alternatif lain dalam hal alokasi sumber daya. Menempatkan semua peluang-peluang ke dalam sebuah daftar (disebut dengan oppotunity 
register) membuatnya terlihat oleh berbagai pihak, dimana beberapa pihak di dalamnya telah mempunyai kapabilitas yang dibutuhkan untuk mewujudkan peluang tersebut. Dengan demikian, peluang-peluang yang teridentifikasi oleh salah satu pihak di dalam perusahaan tersebut dapat dieksploitasi lebih lanjut oleh divisi-divisi atau unit-unit lain dimana peluangpeluang tersebut kemungkinan lebih bermanfaat.

Pengembangan kewirausahaan dapat mengacu model pengembangan kewirausahaan yang dikembangkan oleh Nieman dalam (Charles Mwatsika: 2015), sebagaimana tergambar pada gambar 2 berikut:

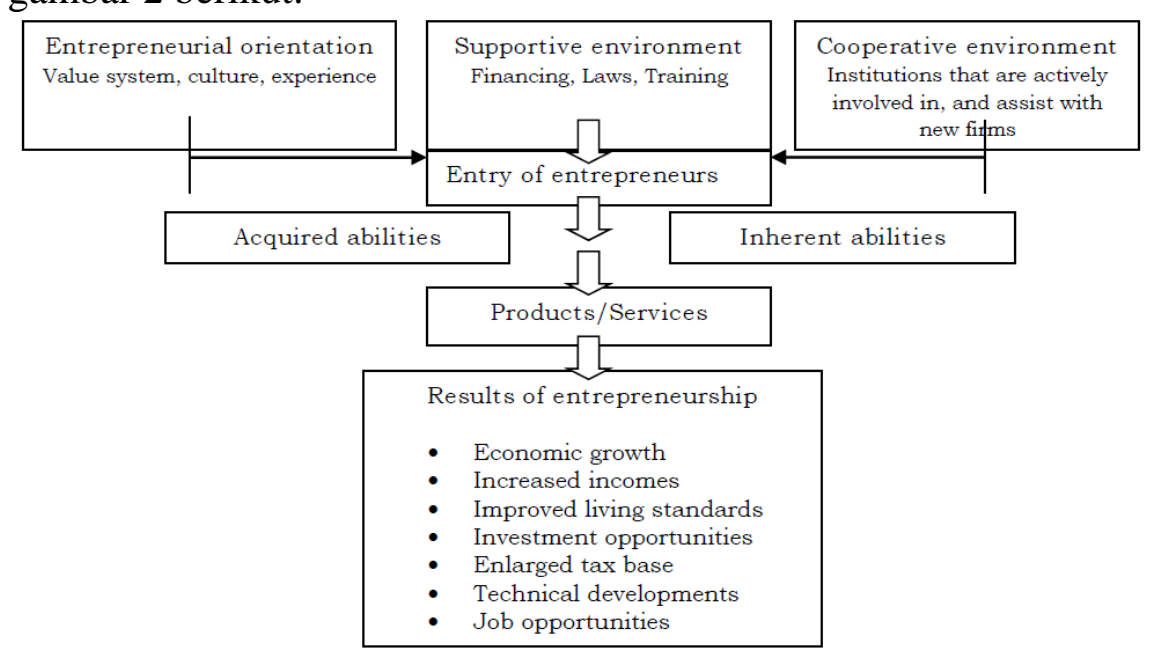

Gambar 2: Model Pengembangan Kewirausahaan Menurut Neiman dalam Charles Mwatsika

Perintah berwirausaha di dalam Al-Quran dijelaskan di Surat Al-Jum'ah ayat 9 - 11 sebagai berikut:

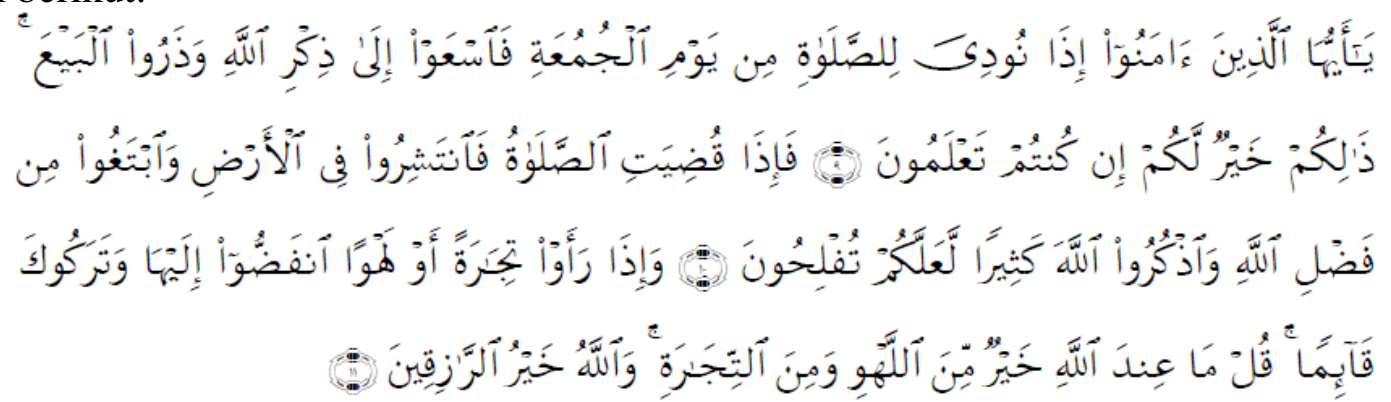

Artinya: Hai orang-orang beriman, apabila diseru untuk menunaikan shalat Jum'at, Maka bersegeralah kamu kepada mengingat Allah dan tinggalkanlah jual beli yang demikian itu lebih baik bagimu jika kamu Mengetahui. Apabila Telah ditunaikan shalat, Maka bertebaranlah kamu di muka bumi; dan carilah karunia Allah dan ingatlah Allah banyak-banyak supaya kamu beruntung. Dan apabila mereka melihat perniagaan atau permainan, mereka bubar untuk menuju kepadanya dan mereka tinggalkan kamu sedang berdiri (berkhotbah). Katakanlah: "Apa yang di sisi Allah lebih baik daripada permainan dan perniagaan", dan Allah sebaik-baik pemberi rezki.

Ayat di atas adalah ayat yang terkait dengan kewirausahaan, bahwa ayat tersebut menganjurkan seorang muslim tidak boleh bermalas-malasan dalam mencari rizki untuk memenuhui kabutuhan hidupnya, karena perintah agar selesei sholat bertebaran di muka bumi mencari rizki yang diungkapkan dalam bentuk " $a m r$ " atau perintah, mengandung arti segera. Kecuali memang waktu untuk istirahat, dan waktu istirahat dipakai sekalian untuk sholat. maka selesei sholat memang beristirahat dan memulihkan tenaga untuk agar bersemamgat dalam bekerja di waktu berikutnya.

Perintah berwirausaha di dalam Al-Quran dijelaskan juga pada Surat Al-Qhashash ayat 77 sebagai berikut: 


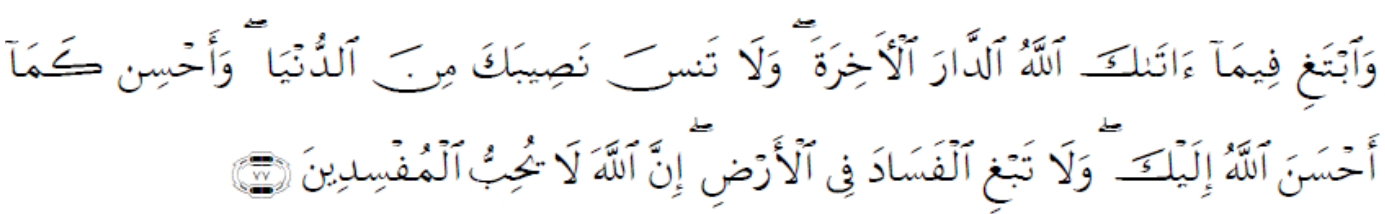

Artinya: Dan carilah pada apa yang telah dianugerahkan Allah kepadamu (kebahagiaan) negeri akhirat, dan janganlah kamu melupakan bahagianmu dari (kenikmatan) duniawi dan berbuat baiklah (kepada orang lain) sebagaimana Allah telah berbuat baik, kepadamu, dan janganlah kamu berbuat kerusakan di (muka) bumi. Sesungguhnya Allah tidak menyukai orang-orang yang berbuat kerusakan.

Ayat di atas juga terkait dengan kewirausahaan yang menegaskan seorang muslim dalam usahanya mencari rizki sebenarnya adalah merupakan amal kebaikan yang bernilai ukhrowi, artinya dalam usaha dan jerih payahnya mencari rizki itu di samping mengandung nilai duniawi yaitu didapatkannya rizki untuk kebutuhan biaya menjalani proses kehidupan, tapi juga mengandung nilai ukhrowi karena diniatkan sebagai sarana untuk mencapai kebahagiaan di akherat juga. yaitu dengan menggunakan apa yang didapatkan dari jerih payahnya untuk kebaikan dan ketaatan kepada Allah SWT., dan proses mencarinya diniatkan sebagai amal kebaikan dan ketaatan.

\section{Etika Kewirausahaan}

Etika merupakan suatu kumpulan pengetahuan mengenai penilaian terhadap perbuatanperbuatan manusia. Maka objek formal etika adalah norma-norma kesusilaan manusia, dan dapat dikatakan juga bahwa etika mempelajari tingkah laku manusia ditinjau dari segi baik dan tidak baik di dalam suatu kondisi yang normatif, yaitu yang melibatkan norma-norma (Amsal Bakhtiar: 2014). Adapun etika bisnis atau wirausaha merujuk pada nilai-nilai normatif yang ada pada masyarakat maupun peraturan perundang-undangan yang berlaku.

Dalam etika berwriausaha perlu ada ketentuan-ketentuan yang mengaturnya, yaitu: (a). Sikap dan perilaku seorang pengusaha harus mengikuti norma yang berlaku dalam suatu negara atau masyarakat; (b). Penampilan yang ditunjukan seorang pengusaha harus selalu apik, sopan, terutama dalam menghadapi situasi atau acara-acara tertentu; (c). Cara berpakaian pengusaha juga harus sopan dan sesuai dengan tempat dan waktu yang berlaku; (d). Cara berbicara seorang pengusaha juga mencerminkan usahanya, sopan, penuh tata karma, tidak menyinggung atau mencela orang lain; (e). Gerak-gerik seorang pengusaha juga dapat menyenangkan orang lain, hindarkan gerak-gerik yang dapat mencurigakan (Kasmir: 2011).

Etika atau norma yang harus ada dalam benak dan jiwa setiap pengusa adalah sebagai berikut: (a). Kejujuran. Seorang pengusaha harus selalu bersikap jujur baik dalam berbicara maupun bertindak. Jujur perlu agar berbagai pihak percaya terhadap apa yang akan dilakukan. Tanpa kejujuran usaha tidak akan maju dan tidak dipercaya konsumen atau mitra kerjanya; (b). Bertanggung jawab. Pengusaha harus bertanggung jawab terhadap segala kegiatan yang dilakukan dalam bidang usahnya. Kawajiban terhadap berbagai pihak harus segera diselesaikan. Tanggung jawab tidak hanya terbatas pada kewajiban, tetapi juga kepada seluruh karyawannya, masyarakat, dan pemerintah; (c). Menepati janji. Pengusaha dituntut untuk selalu menepati janji, misalnya dalam hal pembayaran, pengiriman barang atau penggantian. Sekali saja seorang pengusaha ingkar janji, hilanglah kepercayaan pihak lain terhadapnya. Pengusaha juga harus konsisten terhadap apa yang telah dibuat dan disepakati sebelumnya; (d). Disiplin. Pengusaha dituntut untuk selalu disiplin dalam berbagai kegiatan yang berkaitan dengan usahnya, misalnya dalam hal waktu pembayaran atau pelaporan kegiatan usahanya; (e). Taat hukum. Pengusaha harus selalu patuh dan menaati hokum yang berlaku, baik yang berkaitan dengan masyarakat ataupun pemerintah. Pelanggaran terhadap hukum dan peraturan yang telah dibuatkan berakibat fatal dikemudian hari. Bahkan, hal itu akan menjadi beban moral bagi penguasaha apabila tidak diselesaikan; (f). Suka membantu. Pengusaha secara 
moral harus sanggup membantu berbagai pihak yang memerlukan bantuan. Sikap ringan tangan ini dapat ditunjukkan kepada masyarakat dalam berbagai cara. Pengusaha yang terkesan pelit akan dimusuhi banyak orang; (g). Komitmen dan menghormati. Pengusaha harus komitmen dengan apa yang mereka jalankan dan menghargai komitmen dengan pihak-pihak lain. Pengusaha yang menjunjung tinggi komitmen terhadap apa yang telah diucapkan atau disepakati akan dihargai oleh berbagai pihak. (h). Mengejar prestasi. Pengusaha yang sukses harus selalu berusaha mengejar prestasi setinggi mungkin. Tujuannya agar perusaaan dapat terus bertahan dari waktu kewaktu. Prestasi yang berhasil dicapai perlu terus ditingkatkan. Disamping itu, pengusaha juga harus tahan mental dan tidak mudah putus asa terhadap berbagai kondisi dan situasi yang dihadapinya (Kasmir: 2011).

\section{Proses Kewirausahaan}

Kewirausahaan merupakan sebuah proses yang dapat dikelola. Menurut Hisrich et al dalam (David Wijaya: 2017) kewirausahaan mencakup empat fase mencakup: 1). Identifikasi dan evaluasi peluang; 2). Pengembangan rencana bisnis; 3). Penentuan sumber daya yang diperlukan; dan 4). Pengelolaan perusahaan yang terbentuk. Sedangkan menurut Kuratko proses enterpreneurship memiliki pola yang dimulai dengan mengidentifikasi peluang, kemudian merumuskan konsep bisnis, dan menilai kebutuhan sumber daya dan mendapatkannya, mengimplementasikan konsep dan memperoleh hasil (M. Taufiq Amir: 2016).

\section{Jenis dan Bidang Usaha}

Jenis dan bidang usaha yang dapat digeluti entrepreneur setidaknya terdapat 3 jenis kategori umum jenis usaha (Rusydi Ananda dan Tien Rafida: 2016) yaitu: 1). usaha produksi (manufacturing), 2). usaha perdagangan (trading), dan 3). usaha jasa (service).

Usaha produksi (Manufacturing) adalah usaha yang terkait dengan mengubah bahan baku menjadi produk. Oleh karena itu sumber keunggulan usaha produksi dalam bersaing terkait dengan kualitas, kontinuitas dan harga bahan baku yang dipasok oleh pemasok, serta teknologi produksinya. Usaha produksi diklasifikasikan menjadi dua tingkatan yaitu primer dan skunder. Produk primer mengacu pada penggalian sumber daya alam, atau penggunaan sumber daya berada di dalam bumi. Sedangkan usaha produksi skunder merupakan lanjutannya, sebagai contoh kayu gelondongan dibuat papan (primer), papan dibuat furniture dan interior (skunder), kapas dibuat benang tenun (primer), benang tenun dibuat kain songket (skunder), dan sebagainya.

Usaha perdagangan (Trading) dapat dikelompokkan menjadi usaha retail dan distributor. Usaha retail adalah suatu kegiatan menjual barang atau jasa kepada konsumen akhir, usaha retail ini merupakan mata rantai terakhir dalam penyaluran barang dari produsen sampai kepada konsumen akhir. Usaha distributor atau perdagangan besar adalah segala aktivitas pemasaran (marketing) yang menggerakkan barang dari produsen ke pedagang retail atau ke usaha marketing-marketing lainnya.

Usaha jasa (Service) terkait dengan usaha yang mengandalkan pada sumber daya manusia sebagai keunggulan bersaing. Bidang usaha jasa, selain faktor sumber daya teknologi, keuangan dan pemasaran maka sumber daya manusia sebagai sumber dalam bersaing. Hal ini disebabkan oleh karena sumber daya manusia merupakan sumber daya organisasi yang berhubungan langsung dalam aktivitas pemberian jasa kepada pelanggan/ konsumen. Kotler dan Amstrong dalam Solihin (2007) menjelaskan usaha jasa mengandalkan pemasaran interaktif yang dilakukan entrepreneur kepada pelanggan secara langsung melalui aktivitas pemasaran internal dalam bentuk pemberian berbagai pelatihan yang akan meningkatkan kualitas pelayanan kepada pelanggan. Saat ini usaha di bidang jasa merupakan usaha yang cepat pertumbuhannya, terutama pada bidang usaha kecil. Usaha ini dapat dilakukan dengan 
modal kecil dan terjangkau sampai dengan modal usaha yang besar. Bidang usaha jasa antara lain: usaha jasa konstruksi, usaha dibidang perbankan dan lembaga keuangan, usaha jasa bidang asuransi, usaha jasa properti, usaha jasa transportasi, usaha jasa pengiriman, usaha jasa kesehatan, usaha jasa pariwisata, usaha jasa seni dan entertainment, usaha jasa bidang organisasi, usaha jasa profesi, dan usaha jasa pengetikan dan penerjemahan (Rusydi Ananda dan Tien Rafida: 2016).

\section{METODE PENELITIAN}

Penelitian ini menggunakan metode penelitian deskriptif-kualitatif dengan melakukan kajian toeri dan menggambarkan kondisi/fakta lapangan terkait implementasi entrepreneurship di perguruan tinggi yang disajikan secara sistematis, aktual dan akurat mengenai fakta-fakta, serta hubungan antara fenomena yang diselidiki.

\section{HASIL DAN PEMBAHASAN}

\section{Pengembangan Pendidikan Tinggi Berorientasi Kewirausahaan}

Perguruan tinggi di era globalisasi mengharuskan mengembangkan pendidikan tinggi yang berorientasi kewirausahaan, baik dari aspek proses maupun outcame pendidikan tinggi. Orientasi kewirausahaan perguruan tinggi dapat dilakukan melalui dua strategi. Pertama, perguruan tinggi perlu mengemas kurikulum berbasis kewirausahaan (Curriculum - Based Entrepreneurship) hal ini akan menjadi media menyiapkan lulusan yang memiliki jiwa wirausaha dan siap bersaing di masyarakat dengan berbagai keterampilan. Kedua, perguruan tinggi dikelola dengan ala bisnis (business like) sehingga pemberian layanan public menjadi lebih efisien dan efektif.

\section{Strategi Pengembangan Kurikulum Pendidikan Berbasis Kewirausahaan}

Perkembaangan kurikulum dewasa ini semakin mendapat perhatian dari kalangan ilmuan yang menekuni bidang pengembangan kurikulum, teknologi pendidikan dan administrasi pendidikan. Hal ini sangat wajar karena kurikulum memegang peranan penting sebagai alat pendidikan yang sangat vital dalam kerangka sistem pendidikan nasional. Itulah sebabnya, setiap institusi pendidikan wajib memiliki kurikulum yang sesuai dan serasi dengan kedudukan, fungsi dan peran serta tujuan lembaga tersebut untuk lebih bermutu.

Mutu pendidikan adalah penentu kritis kemajuan suatu bangsa untuk mengarahkan investasinya dalam meningkatkan akses dan mutu pendidikan akan lebih cepat dalam meningkatkan kesejahteraan warga negaranya (Michaelowa, K. 2000). Mutu pendidikan secara simultan menentukan keberhasilan meningkatkan daya saing bangsa. Niscaya bagi Pendidikan Tinggi, untuk dapat bertahan di era globalisasi, dengan upaya peningkatan mutu pendidikan. Pengembangan kurikulum merupakan suatu proses yang menyeluruh dan berkelanjutan. Proses itu sendiri berlangsung secara bertahap berdasarkan mekanisme tertentu. Untuk itu, diperlukan pemahaman yang memadai tentang hal-hal yang mendasari perkembangan kurikulum dan kompetensi. Dalam konteks ini, Perguruan Tinggi harus mengemas kurikulum berbasis kewirausahaan (Curriculum - Based Entrepreneurship) hal ini akan menjadi media menyiapkan lulusan yang memiliki jiwa wirausaha dan siap bersaing di masyarakat dengan berbagai ketrampilan. Sehingga lulusan PT siap untuk menciptakan pekerjaan (ready for use) dan menjadi SDM yang bukan mencari pekerjaan tetapi menciptakan pekerjaan.

Kesadaran akan pentingnya pendidikan kewirausahaan didorong oleh pernyataan Sosiolog David Mc.Clelland bahwa sedikitnya dibutuhkan minimal 2 persen wirausaha dari populasi penduduknya agar suatu negara dapat menjadi negara yang maju (Yulizar Kasih: 2013). Pernyataan ini tentu sangat beralasan karena di beberapa negara maju di dunia jumlah pengusaha melebihi 2 persen. Data menunjukkan Amerika Serikat memiliki 12,5 persen jumlah pengusaha dari total penduduknya. Beberapa negara maju lainnya seperti Jepang 10 persen, 
Inggris 10 persen, Singapura 7,5 persen. Bahkan negara berkembang seperti China 2,5 persen, India 2,5 persen dan Malaysia 2,5 persen. Sedangkan bila dibandingkan dengan Indonesia yang saat ini baru memiliki 0,2 persen jumlah pengusaha dari total penduduk yang mencapai 237 juta jiwa (data 2010) (David Wijaya: 2017). Untuk memenuhi jumlah pengusaha sekitar 4,8 juta orang ( 2 persen), salah satu upaya yang dapat ditempuh adalah melalui pendidikan kewirausahaan di perguruan tinggi sebagai gerbang yang diharapkan dapat menghasilkan wirausaha baru.

Louis Gerstner (CEO IBM) membagi manusia menjadi 4 jenis, yaitu: pertama: menjadi penerima suatu kejadian, kedua: cuma mengamati kejadian, ketiga: tidak sadar ada kejadian dan keempat: membuat sesuatu terjadi. Pendidikan tinggi harus dapat memfasilitasi peserta didik agar menjadi jenis keempat, yaitu sesorang yang mempunyai kemampuan untuk mewujudkan sesuatu di mana sebelumnya orang lain tidak mampu memikirkannya atau mewujudkannya. Dengan kata lain, pendidikan harus menekankan lulusan pada pemilikan jiwa-jiwa kewirausahaan (David Wijaya: 2017).

Strategi mewujudkan pendidikan kewirausahaan di pendidikan tinggi secara lengkap dikemukakan Heri Kuswara dalam (Yulizar Kasih: 2013) yang terdiri dari strategi: (a). Menyusun Kurikulum. Perguruan tinggi harus dengan sungguhsungguh mendesain mata kuliah / materi kewirausahaan meliputi pembuatan silabus, satuan acara perkuliahan (SAP), slide presentasi, modul teori, modul praktikum / praktek, dan pembuatan buku panduan. Idealnya dalam merumuskan kurikulum perguruan tinggi melibatkan praktisi / pelaku usaha dan motivator agar menghasilkan konsep dan gagasan kewirausahaan yang tepat dan sesuai dengan mahasiswa dari berbagai disiplin ilmu; (b). Peningkatan SDM Dosen. Perguruan tinggi harus mampu mempersiapkan tenaga pengajar / dosen yang mampu "5 M" yaitu : mampu memberikan paradigma baru pentingnya kewirausahaan; mampu merubah / mengarahkan mindset mahasiswa menjadi seorang yang berjiwa entrepreneurship; mampu menginspirasi dan memotivasi mahasiswa menjadi SDM yang mandiri; mampu memberikan contoh karya nyata kewirausahaan (barang/jasa) dan menyuguhkan succes story; dan mampu menghasilkan SDM mahasiswa / alumni menjadi seorang intrapreneur atau entrepreneur sukses; (c). Membentuk Entrepreneurship Centre. Perguruan tinggi harus mampu membentuk Pusat Kewirausahaan (entrepreneurship centre) sebagai wadah yang menaungi dan mengelola berbagai kegiatan kewirausahaan mahasiswa dan dosen. Lembaga ini juga akan menjadi fasilitator dan mediator dengan pihak luar (stakeholders) untuk menjalin dan mengembangkan kerjasama agar kegiatan kewirausahaan di kampus maju dan berkembang; (d). Kerjasama dengan Dunia Usaha. Perguruan tinggi harus mampu menjalin dan membina hubungan kerjasama dengan dunia usaha. Kerjasama ini ditujukan untuk (1) meningkatkan kualitas SDM dosen dan mahasiswa, (2) membuka peluang magang usaha bagi mahasiswa dan dosen, (3) membuka peluang kerjasama usaha khususnya untuk mahasiswa / alumni. Dengan kerjasama ini mahasiswa/alumni memperoleh transfer ilmu dan pengalaman dari para pengusahasecara lanngsung yang sangat bermanfaat bila kelak terjun ke dunia usaha. (e). Membentuk Unit Usaha. Perguruan tinggi harus mampu membentuk unit-unit usaha yang dapat dikelola oleh mahasiswa dan dosen sebagai wadah organisasi bisnis tempat menimba pengalaman berbisnis secara langsung. Bentuk atau jenis bisnis dapat disesuaikan dengan minat dan kemampuan mahasiswa dan dosen serta sesuai dengan kemampuan perguruan tinggi. (f). Kerjasama Dengan Institusi Keuangan (Perbankan/Non Perbankan). Perguruan tinggi harus mampu menjalin kerjasama dengan lembaga keuangan, baik perbankan maupun nonperbankan. Tujuan yang akan dicapai dengan kerjasama ini adalah agar mahasiswa yang akan membuka usaha dapat diberikan kemudahan dalam mengakses modal usaha. (g). Entrepreneurship Award. Perguruan tinggi harus mampu pula mendorong dan meningkatkan semangat berwirausaha, sekaligus mendidik semangat berkompetisi secara fair di kalangan mahasiswa. Kompetisi dalam kegiatan kewirausahaan diharapkan dapat menjadi daya tarik 
bagi mahasiswa sehingga muncul minat dan ketertarikan menjadi wirausaha setelah lulus kuliah.

\section{Strategi Pengelolaan Perguruan Tinggi dengan Sistem Ala Bisnis.}

Reformasi pemerintah di bidang pengelolaan keuangan membuktikan bahwa pola pengelolaan administrasi publik dalam era reformasi dan globalisasi yang bercorak desentralisasi dengan penekanan pada sumberdaya manusia sebagai unsur utama dalam pengembangan dinamika pengelolaan pelayanan publik sudah sesuai dengan semangat proses reformasi birokrasi di lingkungan instansi pelayanan publik. Pola pembiayaan yang sentralistik selama ini sangat dirasakan sebagai penghambat oleh banyak instansi pelayanan publik termasuk perguruan tinggi (PT) dalam pengambilan keputusan, di tengah dunia global yang begitu dinamis di mana arus modal, sumber daya dan tenaga kerja mengalir begitu cepat dari satu ke negara ke negara lain tanpa mengenal batas kedaulatan dan wilayah. Situasi tersebut merupakan peluang dan sekaligus ancaman bagi setiap indivindu, kelompok maupun institusi. Bagi yang kreatif dan antisipatif hal itu juga akan dengan mudah dalam mengubah ancaman menjadi peluang melalui pola korporasi untuk membentuk kekuatan dalam memenangkan persaingan. Namun, tidak demikian bagi yang tidak siap secara natural mereka justru akan ditinggalkan atau bahkan menjadi lemah karena sumberdaya yang dimiliki termobilisasi ke tempat lain yang lebih menguntungkan.

Perguruan tinggi menyelenggarakan pendidikan tinggi, penelitian dan pengabdian masyarakat. Pendidikan tinggi merupakan kegiatan dalam upaya menghasilkan manusia terdidik dengan kriteria yang telah ditetapkan. Penelitian merupakan kegiatan telaah kaidah dalam upaya untuk menemukan kebenaran/atau menyelesaikan masalah dalam ilmu pengetahuan, teknologi, dan/atau kesenian. Pengabdian kepada masyarakat merupakan kegiatan yang memanfaatkan ilmu pengetahuan dalam upaya memberikan sumbangan demi kemajuan masyarakat. Perguruan tinggi dapat berbentuk akademi komunitas, akademi, politeknik, sekolah tinggi, institut dan universitas (Richardus Eko Indrajit: 2016).

Perguruan Tinggi memiliki otonomi untuk mengelola sendiri lembaganya sebagai pusat penyelenggaraan Tridharma. Otonomi pengelolaan Perguruan Tinggi dilaksanakan berdasarkan prinsip: a. akuntabilitas; b. transparansi; c.nirlaba; d. penjaminan mutu; dan e. efektivitas dan efisiensi (UU Nomor 12 tahun 2012 Tentang Pendidikan Tinggi pasal 62 dan 63).

Perguruan tinggi merupakan organisasi nirlaba (non for profit organization) yaitu organisasi yang menjalankan perannya tidak mendapatkan keuntungan, namun demikian keseimbangan dalam pemenuhan dana tetap menjadi penting agar organisasi dapat berjalan dengan produktif (Uhar Suharsaputra: 2015). Menurut UU Nomor 12 tahun 2012 pada penjelasan pasal 60 ayat 2 Yang dimaksud dengan "prinsip nirlaba" adalah prinsip kegiatan yang tujuannya tidak untuk mencari laba, sehingga seluruh sisa hasil usaha dari kegiatan harus ditanamkan kembali ke Perguruan Tinggi untuk meningkatkan kapasitas dan/atau mutu layanan Pendidikan.

Pemerintah menyediakan dana Pendidikan Tinggi yang dialokasikan dalam Anggaran Pendapatan dan Belanja Negara (pasal 83). Perguruan Tinggi dapat berperan serta dalam pendanaan Pendidikan Tinggi melalui kerja sama pelaksanaan Tridharma (pasal 85). Dengan demikian, perguruan tinggi negeri memiliki peran serta dalam memperoleh pendanaan pendidikan dengan pengacu pada peraturan perundang-undangan yang berlaku.

Diberlakukannya Undang-undang Nomor 17 Tahun 2003 tentang Keuangan Negara dan Undang-undang Nomor 1 Tahun 2004 tentang Perbendaharaan Negara mencerminkan adanya perubahan sIstem penganggaran tradisional menjadi penganggaran berbasis kinerja. Dengan system penganggaran berbasis kinerja (performance based budgeting), penyusunan dan pelaksanaan anggaran tidak hanya berdasarkan input dan proses saja, tetapi berorientasi 
pada output (hasil kinerja). Adapun sistem untuk meningkatkan pelayanan kepada masyarakat dalam rangka memajukan kesejahteraan umum dan mencerdaskan kehidupan bangsa dibentuk Badan Layanan Umum (BLU) (Pasal 68 UU Nomor 1 tahun 2004).

BLU adalah instansi di lingkungan Pemerintah yang dibentuk untuk memberikan pelayanan kepada masyarakat berupa penyediaan barang dan/atau jasa yang dijual tanpa mengutamakan mencari keuntungan dan dalam melakukan kegiatannya didasarkan pada prinsip efisiensi dan produktivitas (Pasal 1 Ayat 1 Peraturan Pemerintah RI Nomor 23 Tahun 2005 tentang Pengelolaan Keuangan Badan Layanan Umum). BLU memiliki karakteristik sebagai berikut: (a). Berkedudukan sebagai lembaga pemerintah (bukan kekayaan Negara yang dipisahkan); (b). Menghasilkan barang/jasa yang seluruhnya/sebagian dijual kepada publik; (c). Tidak bertujuan mencari keuntungan; (d). Dikelola secara otonom dengan prinsip efisien dan produktivitas ala korporasi; (e). Rencana kerja/anggaran dan pertanggungjawaban dikonsolidasikan pada instansi induk; (f). Pendapatan dan sumbangan dapat digunakan langsung; (g). Pegawai dapat terdiri dari PNS dan Non PNS; (h). Bukan sebagai subjek pajak. BLU diimplementasikan pada satuan-satuan kerja pemerintah yang secara fungsional melaksanakan tugas operasional pelayanan publik, seperti layanan kesehatan, pendidikan, pengelolaan kawasan, dan lisensi, untuk membedakannya dari fungsi pemerintah sebagai regulator dan penentu kebijakan. Praktik ini telah berkembang luas di manca negara berupa upaya pengagenan (agencification) aktifitas yang tidak harus dilakukan oleh lembaga birokrasi murni, tetapi diselenggarakan oleh instansi yang dikelola ala bisnis (business like) sehingga pemberian layanan kepada masyarakat menjadi lebih efisien dan efektif (Sulasi Rongiati: 2011).

Berdasarkan jenis layanan yang diberikan, satker BLU dapat dikelompokkan menjadi 3 (tiga) golongan besar: (a). Penyedia layanan barang dan/atau jasa, misalnya: pendidikan dan pelatihan, kesehatan, penelitian dan pengembangan, serta bidang penyiaran publik; (b). Pengelola wilayah/kawasan tertentu, misalnya: otorita, kawasan pengembangan ekonomi terpadu. (c). Pengelola dana khusus, misalnya: pengelola dana bergulir, rekening dana investasi, dan rekening pembangunan daerah (Dirjen Perbendaharaan Kemenkeu RI: 2013). BLU bidang pendidikan menyelenggarakan pendidikan kepada masyarakat dalam berbagai jenjang, antara lain menengah atas, akademi, institut, universitas, maupun pendidikan lainnya. Saat ini terdapat 3 (tiga) kategori utama BLU bidang pendidikan, yaitu: (a). Pendidikan Tinggi di bawah Kementerian Pendidikan dan Kebudayaan, yang terdiri dari Universitas dan Politeknik penyelenggara pendidikan tinggi yang diperuntukkan bagi masyarakat luas; (b). Pendidikan Tinggi Agama di bawah Kementerian Agama, yang terdiri dari Universitas dan Institut Agama penyelenggara pendidikan tinggi yang diperuntukkan bagi masyarakat luas; (c). Pendidikan Kedinasan di bawah K/L, yang terdiri dari Balai Diklat, Politeknik, Akademi, dan Sekolah Tinggi penyelenggara pendidikan khusus/keahlian yang seluruh/ sebagian lulusannya diperuntukkan memenuhi kebutuhan internal K/L (Dirjen Perbendaharaan Kemenkeu RI: 2013).

Perguruan Tinggi Negeri salah satu instansi yang dijinkan secara penuh untuk menerapkan Pengelolaan Keuangan Badan Layanan Umum (PK-BLU), maka pengelolaan keuangan dapat dilakukan lebih fleksibel, dengan mengutamakan produktivifitas, efisiensi dan efektivitas. Pola pengelolaan keuangan BLU dimaksudkan agar Perguruan Tinggi Negeri sebagai instansi pemerintah dapat meningkatkan pelayananannya kepada pelanggan, dalam hal ini mahasiswa, masyarakat, dan para stakeholder. Perguruan tinggi negeri sebagai satuan pemerintah yang menerapkan BLU dapat mengelola unit-unit usaha sebagai sumber pendapatan BLU perguruan tinggi (Pasal 14 dan 27 PP 23 tahun 2005 tentang PK-BLU).

Berdasarkan kajian di atas, perguruan tinggi negeri yang telah ditetapkan PTN-BLU harus mengembangkan unit-unit usaha perguruan tinggi dengan semangat enterpreneurship 
(kewirausahaan) sehingga akan memberi nilai tambah bagi perguruan tinggi negeri serta meningkatkan pelayanan prima dan kesejahteraan stakeholder kampus.

\section{KESIMPULAN DAN SARAN}

\section{Kesimpulan}

Pendidikan tinggi di era globalisasi mengharuskan mampu melahirkan alumni yang memiliki daya saing, salah satu indikatornya adalah memiliki jiwa kewirausahaan. Untuk itu perguruan tinggi kurikulum pendidikan berbasis kewirausahaan (Curriculum-Based Entrepreneurship) hal ini akan menjadi media menyiapkan lulusan yang memiliki jiwa wirausaha dan siap bersaing di masyarakat dengan berbagai keterampilan. Adapun strategi pendidikan kewirausahaan sebaga berikut: 1). menyusun kurikulum; 2). peningkatan sdm dosen; 3). membentuk entrepreneurship centre; 4). membentuk unit usaha; 5). kerjasama dengan institusi keuangan (perbankan/non perbankan); dan 6). entrepreneurship award. Salain strategi pengembangan kurikulum pendidikan kewirausahaan, perguruan tinggi juga dapat menerapkan tata kelola pendidikan tingg dengan sistem ala bisnis (business like) sehingga pemberian layanan publik menjadi lebih efisien dan efektif.

\section{Saran}

Berdasarkan kesimpulan di atas, maka dapat disarankan kepada pemangku kepentingan pendidikan tinggi sebagai berikut:

1. Strategi peningkatan daya saing alumni perguruan tinggi di era globalisasi dengan penerapan pendidikan kewirausahaan.

2. Strategi pengkatan pelayanan publik di perguruan tinggi dapat menerapkan tata kelola dengan sistem ala bisnis (business like) dengan tetap mengacu peraturan perundangundangan yang berlaku.

\section{DAFTAR RUJUKAN}

Amir, M. Taufiq. 2016. Corporate Entrepreneurship \& Innovation. Jakarta: Kencana

Ananda, Rusydi. dan Rafida, Tien. 2016. Pengantar Wirausaha. Medan: Perdana Publishing

Bakhtiar, Amsal. 2014. Filsafat Ilmu. (Edisi Revisi). Jakarta: Rajawali Pers

Direktorat Jenderal Perbendaharaan Kementerian Keuangan RI. 2013. Manual Pengelolaan SATKER BLU Bidang Layanan Pendidikan. Jakarta

Indrajit, Richardus Eko. 2016. Manajemen Perguruan Tinggi Moderen. Yogyakarta: Preinexus Ireland. at all. 2003. A Model of Strategic Entrepreneurship: The Construct and its Dimensions. Journal of Management. Volume 29. Issue 6. Desember 2003 hal. 963-989. DOI: 10.1016/S0149-2063_03_00086-2,

https://www.sciencedirect.com/science/article/pii/S0149206303000862

Julien, Pierre-Andre. 2007. A Theory of Local Entrepreneurship in the Knowledge Economy. USA: Edward Elgar Publishing Limited

Kasih, Yulizar. 2013. Mewujudkan Pendidikan Kewirausahaan di Perguruan Tinggi melalui Proses Pembelajaran yang Berkelanjutan. Jurnal Ilmiah STIE MDP. Vol. 2 No. 2 Maret 2013 Kasmir. 2011. Kewirausahaan. Jakarta: Rajawali Pers

Michaelowa. K. 2000. Returns to Education in Low Income Countries: Evidence for Africa, (Online) Tersedia: $\quad$ http://www.hwww.de/Projects?Res_Programmes/RP/Development_Processes/VfS_EL_2000_Rev2.pdf

Rongiati, Sulasi. 2011. Analisis Yuridis Pengelolaan Keuangan Badan Layanan Umum Pada Instansi Pemerintah Penyelenggara Layanan Umum. Jurnal NEGARA HUKUM: Vol. 2. No. 1. Juni 2011 
Suharsaputra, Uhar. 2015. Manajemen Pendidikan Perguruan Tinggi. Bandung: Refika Aditama

Takdir S, Dedy. Dkk. 2015. Kewirausahaan. Yogyakarta: Wijana Mahadi Karya

UU Nomor 12 tahun 2012 Tentang Pendidikan Tinggi

Wijaya, David. 2017. Pendidikan Kewirausahaan Untuk Sekolah dan Perguruan Tinggi.

Yogyakarta: Pustaka Pelajar 